\title{
Stable carbon and nitrogen isotope variations in canine dentine growth layers of Kerguelen southern elephant seals
}

\author{
Céline Martin $^{1, *}$, Ilham Bentaleb ${ }^{1}$, Stéphanie Steelandt ${ }^{1,2}$, Christophe Guinet $^{3}$ \\ ${ }^{1}$ Université Montpellier II, Institut des Sciences de l'Evolution (CNRS, IRD), Place Eugène Bataillon, CC061, 34095, \\ Montpellier, Cedex 5 France \\ ${ }^{2}$ Université Laval Québec, Département de Géographie, Québec, Canada G1V 0A6 \\ ${ }^{3}$ Centre d'Etudes Biologiques de Chizé, 79360 Villiers-en-Bois, France
}

\begin{abstract}
Foraging behaviour of mammals, namely the change in distribution and trophic levels from juvenile stage to adulthood, can be investigated by measuring $\delta^{13} \mathrm{C}$ and $\delta^{15} \mathrm{~N}$ stable isotopes for layers deposited in a growing tooth. For the first time, we describe geographic differences in the ontogeny of foraging strategies and in the niche partitioning process according to sex and age of a highly sexually dimorphic species: the southern elephant seal Mirounga leonina. Canines from 8 males and 6 females were analysed for $\delta^{13} \mathrm{C}$ and $\delta^{15} \mathrm{~N}$ stable isotope signatures. To assess intra-individual variability, instead of analysing collagen we analysed the bulk dentine within each of the 4 growth layers deposited annually. The $\delta^{13} \mathrm{C}$ signature revealed that, in individuals of 1 to $4 \mathrm{yr}$ of age, teeth of both males and females exhibited large intra-individual variation in $\delta^{13} \mathrm{C}$, suggesting that juveniles were foraging over a broad range of marine habitats encompassing both sub-Antarctic and Antarctic waters. Four out of the 6 teeth taken from females were collected on individuals younger than $4 \mathrm{yr}$, preventing investigation of longer-term changes. A $\delta^{13} \mathrm{C}$ pattern emerged for males older than $4 \mathrm{yr}$ : individuals became resident to either a subAntarctic $(-17 \%)$ or an Antarctic $(-20 \%$, both values reported as deviations from the Vienna PeeDee Belemnite standard) foraging habitat, with a decrease in intra-individual variability. Up to the age of $4 \mathrm{yr}$, juvenile males were at a slightly higher trophic level than juvenile females, but by the age of $4 \mathrm{yr}$, while their $\delta^{13} \mathrm{C}$ signature revealed that they were faithful to their foraging habitat, males exhibited a significant increase in their trophic levels, as shown by their $\delta^{15} \mathrm{~N}$ signature.
\end{abstract}

KEY WORDS: Mirounga leonina $\cdot$ Dentine $\delta^{13} \mathrm{C}$ and $\delta^{15} \mathrm{~N} \cdot$ Trophic level $\cdot$ Foraging habitat

\section{INTRODUCTION}

Investigating the foraging strategies of top predators within an ecosystem is an important step towards understanding the functioning of an ecological community, on both spatial and temporal scales. Intraspecific competition has been identified as a significant component of species niche width (Polis 1984, Schoener 1989). Many species exhibit significant variation in foraging strategy with age, sex or sizeclass for similar habitats (Bolnick et al. 2003). How- ever, only a few studies have addressed the ontogeny of niche partitioning in sexually dimorphic species, since such studies are difficult in practice, particularly in the oceanic environment (e.g. Field et al. 2005, Field et al. 2007b). Ontogenetic shifts in morphology, habitat use and foraging strategy may promote population stability more effectively over evolutionary time (Polis 1984).

Different methods and techniques based on diet are available in ecology foraging studies, each having its own strengths and weaknesses. Conventional 
techniques of stomach lavaging or faecal analysis may provide high-resolution species-specific data directly related to digestion transit rate, and over a relatively short period. Stable isotopes, while lacking in high-resolution species-specific data over a short timeframe, can reveal surprising ecological features of a species by summarizing trophic information over a broader time and space window as compared to traditional dietary studies. Stable isotopic carbon and nitrogen analysis is now increasingly used to investigate the feeding habits of major consumers (Newsome et al. 2007a, Newsome et al. 2010). The $\delta^{15} \mathrm{~N}$ measurements serve as indicators of consumer trophic position, as consumer tissues are typically enriched in ${ }^{15} \mathrm{~N}$ relative to their food (DeNiro \& Epstein 1981, McCutchan et al. 2003), with an average increase of $3.3 \pm 0.26 \%$ between trophic levels (McCutchan et al. 2003). In contrast, $\delta^{13} \mathrm{C}$ values vary little between trophic levels but are often used to indicate the geographic source of prey items due to well documented variation in $\delta^{13} \mathrm{C}$ with different photosynthetic processes (Hobson 1999). In the marine environment, $\delta^{13} \mathrm{C}$ values indicate latitudinal variation in consumer foraging areas in contribution to food intake (Kelly 2000, Cherel \& Hobson 2007). Moreover, variations in the $\delta^{13} \mathrm{C}$ values of some species can be linked to benthic versus pelagic, or nearshore versus offshore feeding habitats (Hobson et al. 1994, Michener \& Schell 1994, Hobson 1999, Cherel $\&$ Hobson 2007). These methods are based on the principle that 'you are what you eat' (DeNiro \& Epstein 1978), i.e. the biochemical composition of molecules and tissues of consumers is a reflection of their diet over the period of synthesis. Some tissues, such as dentine in pinniped teeth, are synthesised throughout the life of the animal (McCann 1993), and both their protein and calcified components appear to be metabolically inert following formation. Thus the life history (in terms of diet and trophic status) of individual animals may be reflected in the incremental pattern of dentine growth, represented as changes in the chemical composition of each growth layer (Hobson \& Sease 1998, Newsome et al. 2007b, Hanson et al. 2009).

Southern elephant seals Mirounga leonina (SES) provide the most extreme example of sexual dimorphism of all mammals (Andersson 1994), adult males sometimes weighing $>10$ times more than females. The foraging strategies of SES at various ages, between the sexes or by size-class is poorly described. Boyd et al. (1994) estimated that a $2500 \mathrm{~kg}$ male has a daily energy requirement 3 times higher than that of a $500 \mathrm{~kg}$ female. Adult males may therefore adopt different behaviours to meet their higher energy requirements (Hindell et al. 1991). Understanding the intra-specific variability of SES foraging ecology may shed light on the recent population decline of this species (McMahon et al. 2005). Indeed, longterm monitoring of SES from the Kerguelen Islands suggests that (1) a major change took place in the 1970 s, as evidenced by a severe population decrease (McCann 1985, Guinet et al. 1992), and (2) the number of females breeding on the Kerguelen Islands has been stable over the past $20 \mathrm{yr}$ (Authier et al. 2011). The underlying causes of these population changes are unclear, but are likely related to large-scale ecosystem changes (Weimerskirch et al. 2003). Therefore, it is critical to assess whether age- or sex-related differences in SES foraging ecology have occurred.

Here we present a study of the individual ontogeny of foraging strategy according to sex and age of SES belonging to the Kerguelen Island population. (1) In order to create intra-individual life history reconstructions, we explored a method based on analysis of $\delta^{13} \mathrm{C}$ and $\delta^{15} \mathrm{~N}$ composition of the bulk dentine collected along discrete growth layers of the canines. We also measured C:N ratios as an indicator of good dentine preservation.(2) We investigated the longitudinal foraging shift according to sex and age of individuals from the analysis conducted on 14 SES teeth.

\section{MATERIALS AND METHODS}

Canine teeth were collected from male and female SES that had died of natural causes during breeding and moulting haul-outs on the Kerguelen Islands (from $48^{\circ} 35^{\prime}$ to $49^{\circ} 54^{\prime} \mathrm{S}$, and from $68^{\circ} 43^{\prime}$ to $70^{\circ} 35^{\prime} \mathrm{E}$ ), Southern Ocean (Fig. 1). Canines were selected for this study in preference to postcanines, because these teeth grow continuously and without the pulp cavity closing, allowing the deposition of new dentine layers throughout the life of the individual (McCann 1993). In this study we analysed canines from 14 individuals ( 8 males and 6 females, all found dead between 2005 and 2007).

Each tooth was first coated with resin and then cut longitudinally with a diamond-wire saw, with the cut oriented along the bucco-lingual plane, as close to the centre line as possible.

Growth layers were observed under diffused light and counted 3 times by 2 of the authors (C. Martin and S. Steedlandt) in order to estimate the deposition time in years. According to Laws (1952), 2 opaque bands and 2 translucent bands are formed each year of life (Fig. 2). Alternating dark and clear layers are 


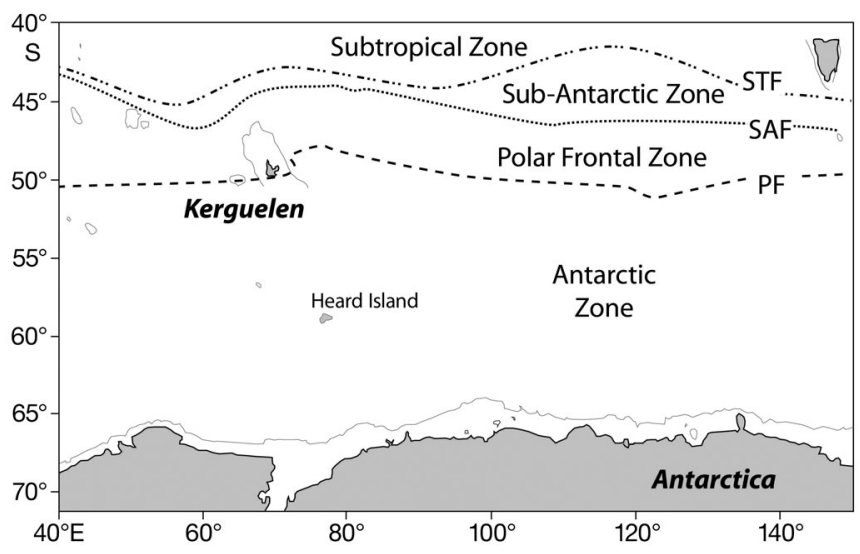

Fig. 1. Mirounga leonina. Location of Kerguelen Islands and oceanographic fronts and zones in the Southern Indian Ocean. PF: polar front; SAF: sub-Antarctic Front; STF: subtropical front

related to the succession of shore visits and at-sea foraging trips. This 4-band structure defines a single growth layer group (GLG) that is deposited over $1 \mathrm{yr}$. A GLG is a repeating pattern of adjacent groups of incremental growth layers within the dentine, which is defined as a countable unit involving a change (Perrin \& Myrick 1980). We defined foetal dentine as the layer deposited in utero, since SES permanent teeth start to grow during intra-uterine life (Laws 1953). Each GLG was then assigned to a 'year of dentine formation' corresponding to the year of the animal's growth during which the layer of dentine was deposited. Each band was assigned to one-fourth of a year.

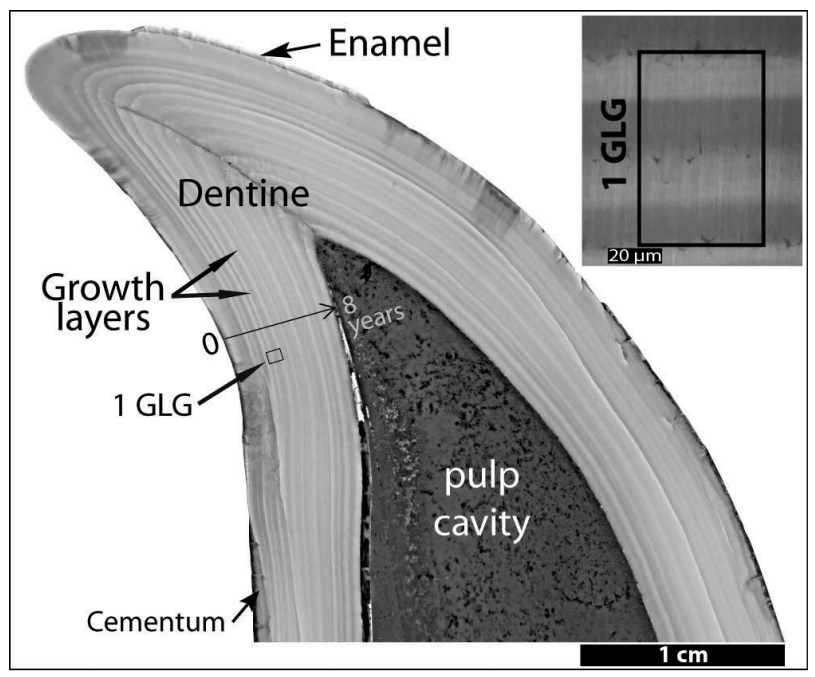

Fig. 2. Mirounga leonina. Microstructure of canine tooth showing internal dentine growth layers. A growth layer group (GLG) corresponds to 2 opaque bands and 2 translucent bands, formed each year
Using a MicroMill sampler (Merkantek), 1 mg of bulk dentine was extracted and placed into tin capsules for isotope analysis of samples from individual growth layers (Dettman \& Lohmann 1995, Wurster et al. 1999). Dentine was drilled to a depth of $<200 \mu \mathrm{m}$ to reduce the chance of mixing with other layers. Consecutive samples were taken from each successive growth band. A total of 311 powder samples were collected from the dentine of the 14 drilled teeth.

Organic matter $\delta^{13} \mathrm{C}$ and $\delta^{15} \mathrm{~N}$ and $\mathrm{C}$ and $\mathrm{N}$ contents of the bulk dentine powder were determined using an EA3000-IRMS elemental analyser (EuroVector) coupled to an Optima continuous-flow mass spectrometer (Micromass) at the University of Montpellier II. Stable isotope results are reported as per mille (\%o) deviations from the Vienna PeeDee Belemnite (VPDB) standard. Precisions (SD) on internal standards were $< \pm 0.2 \%$ for both $\delta^{13} \mathrm{C}$ and $\delta^{15} \mathrm{~N}$. In order to test the impact of the inorganic dentine portion on the isotopic organic results, untreated and acidtreated samples $(\sim 10)$ were analysed, but no significant differences emerged ( $\mathrm{SD}= \pm 0.02 \%$ ). Using the $\mathrm{C}$ and $\mathrm{N}$ contents of the IAEA-NO-3 $(\mathrm{N} \%=13)$, and alanine $(\mathrm{C}=40.41 \%, \mathrm{~N}=15.71 \%)$, the percent $\mathrm{C}$ and $\mathrm{N}$ contents of the dentine powder samples were measured. The analytical precision was $\sim 1 \%$ for both $\mathrm{C}$ and $\mathrm{N}$, using the alanine and NO-3 standards respectively.

\section{RESULTS}

GLG counts allowed age estimation of each analysed specimen. Age at death ranged from 3 to $11 \mathrm{yr}$ for males and was $\sim 4$ yr for females (Table S1 in the supplement available at www.int-res.com/articles/ suppl/m439p295_supp.xls). The number of dentine samples analysed for each individual tooth varied from 7 to 36, with a mean of 4 samples per 1 yr GLG. For the older specimens, the external parts of the canines were often worn out. As dentine is laid down from the enamel surface to the pulp cavity, the canine wearing could, for some individuals, mean loss of isotopic results for the early years of life. A thin black line was sometimes observed in the first dentine layer; dentine deposited between the enamel and this neonatal line was interpreted as having been synthesised in utero.

The dentine isotopic signatures for each of the 14 teeth covered a wide range, with the individual-tooth mean for $\delta^{13} \mathrm{C}$ varying from -19.9 to $-16.9 \%$, and for $\delta^{15} \mathrm{~N}$ from 11.5 to $13.8 \%$ (Table S1 \& S2 in the supple- 
ment available at www.int-res.com/articles/suppl/ m439p295_supp.xls). C:N mean values ranged from 3 to 3.5 .

\section{Carbon and nitrogen contents}

$\mathrm{C}$ and $\mathrm{N}$ contents of the dentine of male and female specimens was found to vary from 10 to $15 \%$ and from 3.5 to $4.5 \%$ respectively (Fig. 3A,B). All the C:N values ranged from 2.9 to 3.6, except for some samples of EM-KER-2005-20, EM-KER-2005-14 and EMKER-2005-21, all male specimens (Fig. 3C, Fig. 4E). It is interesting to note that most of our C:N data are in the range of that described in the pioneer work of DeNiro (1985), which became a useful tool for identifying well preserved collagen. Since DeNiro's publi-
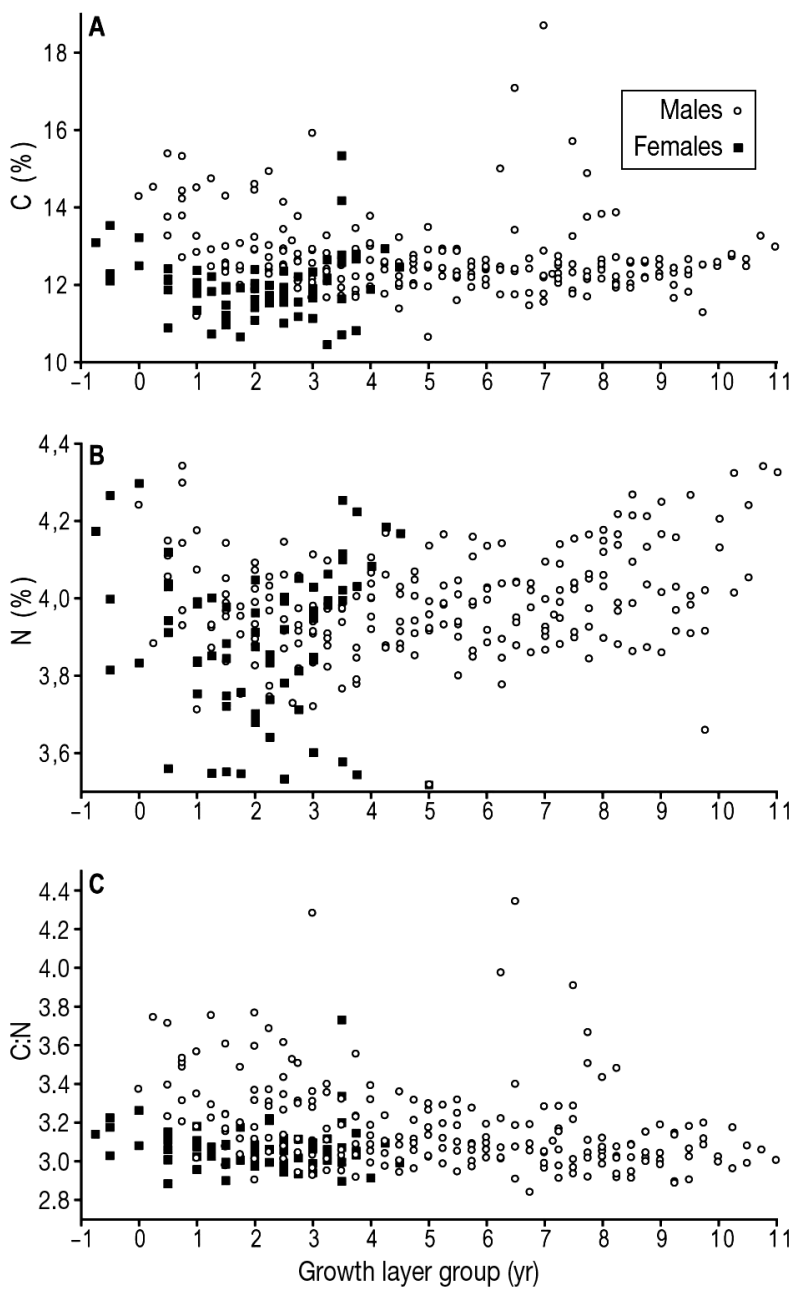

Fig. 3. Mirounga leonina. (A) Carbon content. (B) Nitrogen content. (C) $\mathrm{C}: \mathrm{N}$ ratios in dentine growth layers of canines from males and females cation, C:N threshold values (from 2.9 to 3.6) have been used to identify post mortem diagenetic alteration preventing the use of the stable isotopes, or at least raising an alert to potential impacts on isotopic integrity (Ambrose 1990, Schulting et al. 2008 among others). The C:N ratios between bulk dentine and collagen are very similar, but $\mathrm{C}$ and $\mathrm{N}$ contents are lower in the bulk dentine as compared with the collagen (see values in Schulting et al. 2008). The lower C and $\mathrm{N}$ content in dentine is likely due to the contribution of mineral hydroxyapatite in the total weight of dentine powder, while collagen is a pure organicextracted material. Hence we suggest that the use of bulk dentine material instead of collagen for isotopic analysis is an efficient alternative, not only because it is less time-consuming than collagen extraction, but also because it allows working to a better scale.

\section{Nitrogen isotopes in dentine growth layer}

$\delta^{15} \mathrm{~N}$ time-series revealed important variations from in utero life up to $1.5 \mathrm{yr}$ (Fig. 4A,B; Fig. 5A). Relatively high values (from 13 to $15 \%$ ) were recorded during the first year of the animal's life, to be followed by an abrupt decrease after the first year (down to $10 \%$ for males and $11 \%$ for females). From Year 1.5 to Year 2, both female and male $\delta^{15} \mathrm{~N}$ dentine profiles showed an intra-annual variability of about $0.6 \%$ (Fig. 4A,B). From Year 2 to Year 4, no variation in $\delta^{15} \mathrm{~N}$ values with age could be detected either for males or females ( $t$-test, $t=-0.42, \mathrm{p}=0.681$; see Fig. $4 \mathrm{~A}, \mathrm{~B}$ and $5 \mathrm{~A}) . \delta^{15} \mathrm{~N}$ values for males overlapped those for females (Fig. 5A), but were significantly higher $($ mean $=11.9 \%$; range from 11.4 to $12.7 \%$ o) than those for females (mean $=11.1 \%$; range from 10.6 to $11.4 \% ; t=-5.26, \mathrm{p}<0.0001)$. For males older than $4 \mathrm{yr}$, the $\delta^{15} \mathrm{~N}$ values of dentine increased significantly with age (ANOVA, $F=8.858, \mathrm{p}<0.0001$; Fig. 4A, 5A). This could not be investigated for females due to the shorter time-series for females (Fig. 4B, 5A).

\section{Carbon isotopes in dentine growth layer}

$\delta^{13} \mathrm{C}$ time-series revealed abrupt changes during the in utero stage and the first years of life (Fig. 4C,D, 5B). Most specimens exhibited the following pattern: at $\sim 1 \mathrm{yr}$, the $\delta^{13} \mathrm{C}$ signal dropped abruptly, then increased during the second year of life by about $2 \%$ for both males and females. $\delta^{13} \mathrm{C}$ signatures during the prenatal period presented a wide inter-specimen 

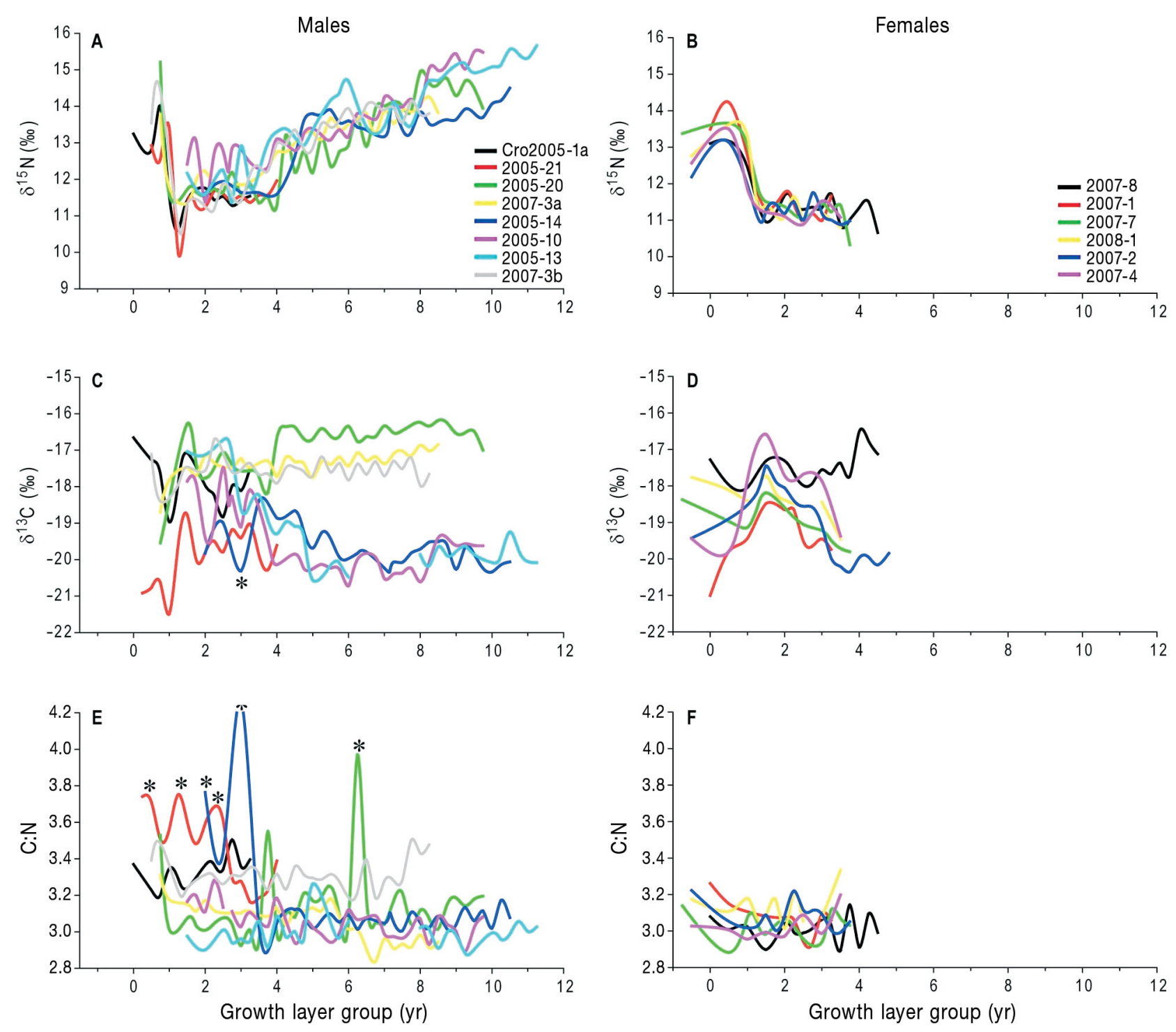

Fig. 4. Mirounga leonina. For males and females, intra-tooth isotopic profiles versus growth layer group (GLG) for (A \& B) nitrogen, (C \& D) carbon, (E \& F) C:N ratios. *: outliers (C:N > 3.6) suggesting altered samples or errors in measurement

variation (range from -21 to $-16.6 \%$ ), with no differences between males and females $(t=-0.37, \mathrm{p}=$ 0.733). $\delta^{13} \mathrm{C}$ values exhibited a similar range (from -20.3 to $-16.7 \%$ ), with no differences between males and females between 2 and $4 \mathrm{yr}$ of age $(F=0.485, \mathrm{p}=$ 0.4943). For males, the distribution of $\delta^{13} \mathrm{C}$ dentine values exhibited 2 clearly distinct patterns $(\mathrm{F}=$ 240.199, $\mathrm{p}<0.0001$ ), with one distribution centred upon $-17 \%$ o $\pm .5 \%$ o $(\mathrm{n}=3)$ and a second one centred upon $-20 \% \pm 0.3 \%$ o $(\mathrm{n}=3$; Fig. 4C, 5B). Intraspecimen $\delta^{13} \mathrm{C}$ values for males older than $4 \mathrm{yr}$ did not vary significantly with age $(F=0.375, \mathrm{p}=0.86)$. Male intra-individual $\delta^{13} \mathrm{C}$ variability was significantly higher for the 2 to 4 yr age-class $(0.54 \pm 0.25 \%$, $\mathrm{n}=8$ ), as compared to individuals older than $4 \mathrm{yr}$ $(0.30 \pm 0.11 \%, \mathrm{n}=8 ; F=4.15, \mathrm{p}<0.01)$. No difference was detected in $\delta^{13} \mathrm{C}$ variability for the 2 to $4 \mathrm{yr}$ age class between males and females (male $=0.54 \pm$ $0.25 \%$, $\mathrm{n}=8$; female $=0.51 \pm 0.26 \%, \mathrm{n}=6 ; F=0.567$, $\mathrm{p}=0.74$ ). For males older than $4 \mathrm{yr}$, no difference was found in the mean variance of $\delta^{13} \mathrm{C}$ for the 5 males with a $\delta^{13} \mathrm{C}$ distribution centred upon $-20 \%$ as compared to the 3 males with a $\delta^{13} \mathrm{C}$ distribution centred upon $17 \%$ ( $0.25 \%$ versus $0.35 \%$; p > 0.05). The 2 females older than 4 yr presented 2 distinct mean $\delta^{13} \mathrm{C}$ values ( - 17\% and $-20 \%$; Fig. $\left.4 \mathrm{D}, 5 \mathrm{~B}\right)$, similar to those observed in males, but more data on females are needed. 

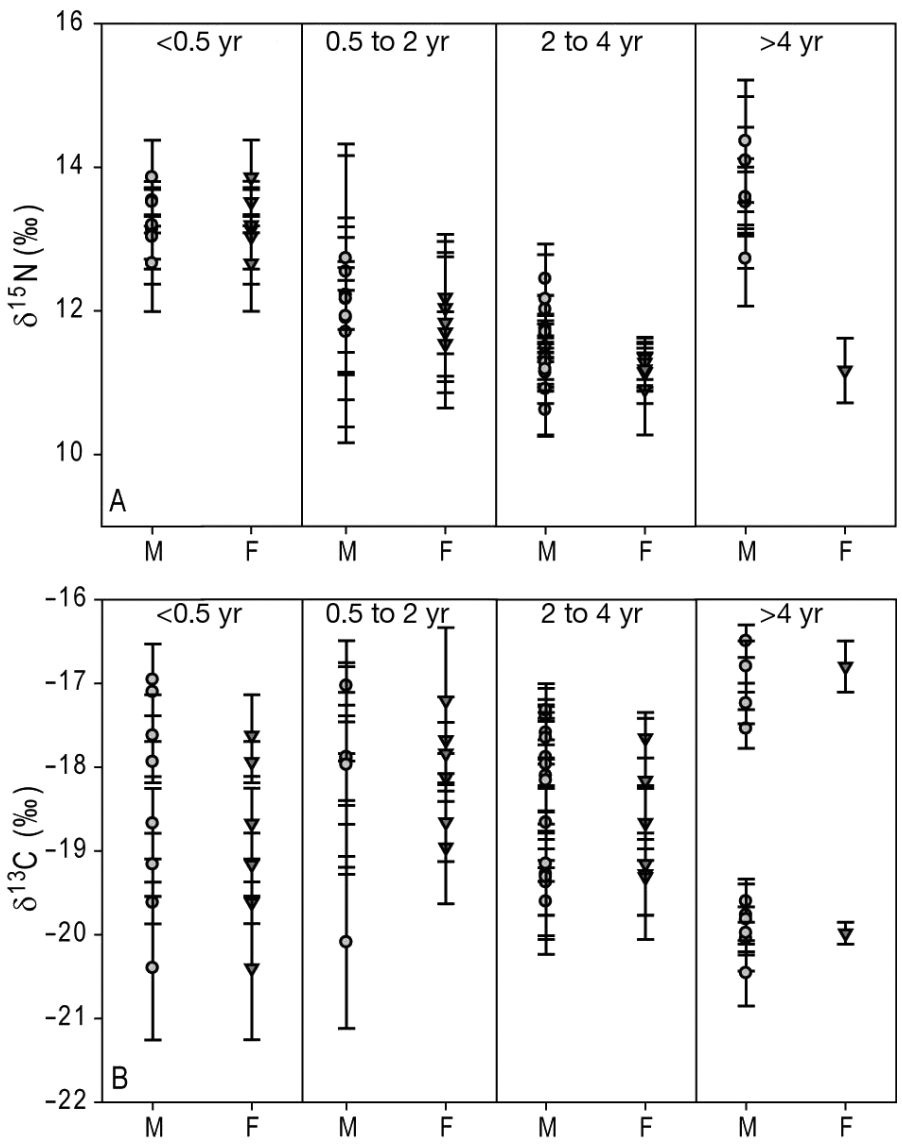

Fig. 5. Mirounga leonina. Isotopic results for (A) $\delta^{15} \mathrm{~N}$, (B) $\delta^{13} \mathrm{C}$ by age category for males and females. Each point corresponds to isotopic mean for considered period \pm SD per subject

\section{DISCUSSION}

We report here, for the first time, the long-term intra- and inter-individual variations in $\mathrm{C}: \mathrm{N}$ ratios and isotopic niche $\left(\delta^{13} \mathrm{C}\right.$ and $\left.\delta^{15} \mathrm{~N}\right)$ of SES, using dentine as an archival tissue. Our data reveal ontogenetic changes in foraging behaviour.

Dentine C:N ratios (Fig. 4E,F), measured at the intra-individual level, show that all but 6 data points (see asterisks on Fig. 4E) are within the limits of C:N ratios (from 2.9 to 3.6) prescribed by scientific 'collagen isotopic users' for identifying well preserved material. The 6 samples corresponding to the $6 \mathrm{C}: \mathrm{N}$ outliers were not characterized by obvious altered isotopic values except for one sample, from individual 2005-14-3 (Fig. 4C, Table 2). Hence, we suggest that bulk tooth dentine can be considered an efficient alternative material for SES isotopic ecological studies as compared to collagen. This analytical approach allows us to make first attempts at SES life history reconstruction at an intra-individual level and at an intra-annual timescale.

Typical enriched $\delta^{15} \mathrm{~N}$ values are observed during the first year of life of juvenile males and females (Fig. 4A,B). This may be related to the metabolic routing of milk proteins and lipids during nursing. Other isotopic studies of pinniped teeth have described a similar pattern (Hobson \& Sease 1998, Newsome et al. 2006). Significant $\delta^{15} \mathrm{~N}$ enrichment takes place between females and their pups during foetal growth and lactation, because the nursing pup is 'consuming its mother' and therefore should occupy a trophic level higher than its mother (Jenkins et al. 2001). This has been previously shown for SES using mother-pup blood samples (Ducatez et al. 2008). According to intra-tooth results for males and females, the lactation signature (increase of $\delta^{15} \mathrm{~N}$ values) of SES is detected between birth and 6 to 9 mo of age (Fig. 4A,B). Maximum $\delta^{15} \mathrm{~N}$ signature, followed by decreasing values (suggesting SES weaning) takes place between 6 and 9 mon (Fig. 4A,B). However, weaning of SES born on the Kerguelen Islands occurs after $\sim 3$ wk (Laws 1953, Guinet 1991). Isotopic equilibration of dentine after diet change has been estimated to take 1 to 4 mo (Balasse et al. 2001), so it is plausible that milk-derived $\delta^{15} \mathrm{~N}$ and $\delta^{13} \mathrm{C}$ signals could influence the isotopic profile throughout the first 5 mo of post-natal dentine growth. Moreover, before going to sea, weanlings undergo a post-weaning fast of from 3 to $7 \mathrm{wk}$, a period during which they rely on fat stores derived from their mother's milk (Ling \& Bryden 1992). McMahon et al. (2000) suggest that pup weight at weaning influences pup survival over the first year, and maternal investment lasts over that year. Moreover, McConnell et al. (2002) estimated the time to starvation at sea was between 70 and $80 \mathrm{~d}$. Hence during the first fasting months spent at sea, the highest $\delta^{15} \mathrm{~N}$ is expected. Moreover, the concomitant $\delta^{13} \mathrm{C}$ depletion suggests that carbon from stored fats is mobilized to the carbon pool available for survival.

Errors in estimating age via GLG counts may also account for part of this apparent delayed weaning age, the main differences between 2 independent GLG counts always involving the first growth layers. This larger uncertainty during early life can be explained by the more complex haul-out pattern of young SES. Juveniles exhibit a variable number of haul-outs, ranging from 1 to 3 in their first year of life to only 1 (for females) in their third year (Carrick and Ingham 1962, Field et al. 2005). This results in a varying number of dentine layers deposited during early life among individuals. This and our sampling resolu- 
tion (maximum 4 samples $\mathrm{yr}^{-1}$ of dentine deposition) may contribute to part of the gap between SES life history (lactation, weaning) and isotopic signal, especially for juvenile history. However, after 3 or $4 \mathrm{yr}$, the GLG pattern becomes very clear and the error in GLG counting is minimal. Our sampling resolution was sufficient to describe the SES foraging strategy evolution with age, and the difference in this evolution between sexes. Thus, the delay between diet and isotopic record in teeth and the GLG counts resolution are not regarded as limits in this study.

The isotopic values stabilised after a systematic decrease of $\delta^{15} \mathrm{~N}$ and increase of $\delta^{13} \mathrm{C}$, corresponding to the transition period between weaning, the postweaning fast and foraging independence (Fig. 4). Around $1.5 \mathrm{yr}$ we consider that the isotopic signal in teeth is no longer under maternal influence.

Between the ages of 2 and 4, male and female dentine $\delta^{15} \mathrm{~N}$ values overlapped to a large extent, although males exhibited greater variability, and some individuals showed higher $\delta^{15} \mathrm{~N}$ values than females (Fig. 5A). The smaller range of amplitude and lower mean value of female $\delta^{15} \mathrm{~N}$ compared with those of males suggests that females may occupy a narrower and on average lower trophic level than males of the same age. As no $\delta^{13} \mathrm{C}$ difference between juvenile males and females was noticed, juvenile males and females appear to mainly forage on similar resources, probably with a sex-related difference in prey size or species, since large fish and squid have higher trophic positions than small pelagic fish (Cherel et al. 2008). This finding is consistent with the results obtained by Field et al. (2007a) and Newland et al. (2009), who relied on fatty acid and stomach content analysis of individuals at Macquarie Island, and with those obtained by Bailleul et al. (2010) at Kerguelen Island using stable isotopes. However in the latter case no differences in $\delta^{15} \mathrm{~N}$ in blood samples were detected between males and females younger than $4 \mathrm{yr}$. Such differences in results between methods using teeth and blood could be related to the faster turnover of the blood isotopic signature as compared to the dentine tissue which, once deposited, does not change. It might also be related to the smaller sample size of individuals used in our study as compared to sample size in the blood-based study of Bailleul et al. (2010).

For males older than 4 yr, a significant linear increase in dentinal $\delta^{15} \mathrm{~N}$ with age was observed, while no change in $\delta^{13} \mathrm{C}$ was detected, indicating that males increased their trophic level while remaining in the same foraging habitat. Our results are important since they stem from a longitudinal analysis and are in agreement with cross-sectional isotopic studies of SES blood, which suggested that larger males have higher $\delta^{15} \mathrm{~N}$ values (Bailleul et al. 2010). Furthermore, Bailleul et al. (2010) showed from tracking data that males older than 3 or $4 \mathrm{yr}$ concentrated most of their foraging effort on the Kerguelen and Antarctic shelf, while younger males, like females, foraged in oceanic waters. This increase in trophic level of males is concomitant with a second growth spurt observed in males (McLaren, 1993). These results suggest that the increasing size of males allows them to expand and increase their foraging niche (Polis, 1984), and this may reduce intra-specific competition and increase the likelihood of successful individual foraging.

The time-series for females were shorter and only a limited number of teeth from females were from individuals older than $4 \mathrm{yr}$. This suggests that most females found dead on the Kerguelen beaches were likely to be primiparous (see Pistorius et al. 2001), and, as such, were experiencing higher mortality when giving birth for the first time as compared to older, multiparous females. More teeth data are needed for females older than 4 yr. Stable isotopic analysis performed on blood collected on juveniles and adult Kerguelen SES females failed to identify any significant increase of $\delta^{15} \mathrm{~N}$ with size, a measure used as a proxy of age (Bailleul et al. 2010). However data obtained on female diets from Macquarie and Heard Islands suggest ontogenetic differences in relation to female age classes. More work on teeth or other archival and continuously growing tissues, such as nails, is needed to resolve these apparent contradictions (Field et al. 2007b, Newland et al. 2009).

For males older than $4 \mathrm{yr}$, the 2 distinct groups of $\delta^{13} \mathrm{C}$ signatures suggested that males used at least 2 distinct foraging regions (Fig. 5). In agreement with previous satellite tracking, some individuals appeared to migrate to high-latitude Antarctic waters, while others favoured the lower latitudes of the Polar Frontal Zone (Bailleul et al. 2007, 2010; Biuw et al. 2007). Indeed, the $\delta^{13} \mathrm{C}$ values in the tissues of organisms in the Southern Ocean vary with latitude (Kelly 2000, Cherel \& Hobson 2007), reflecting the geographical $\delta^{13} \mathrm{C}$ gradient well defined in particulate organic matter and phytoplankton from surface waters (Rau et al. 1989, Bentaleb et al. 1998). This gradient ranges from high $\delta^{13} \mathrm{C}$ values in warm subtropical waters in the north to low values in cold Antarctic waters to the south (Goericke \& Fry 1994, Bentaleb \& Fontugne 1996, Trull \& Armand 2001). We therefore expect that the $\delta^{13} \mathrm{C}$ gradient at the base of the food chain is reflected in the isotopic signature of SES tooth profiles, with higher values 
$(-17 \%)$ reflecting a foraging habitat in the Polar Frontal Zone and lower values $(-20 \%$ o) in Antarctic waters. The $\delta^{13} \mathrm{C}$ latitudinal gradient we observed in the case of SES teeth has also been described in blood $\delta^{13} \mathrm{C}$ values of both SES and penguins (Cherel \& Hobson 2007, Cherel et al. 2007, Ducatez et al. 2008). Blood isotopic values of -19 and $-16 \%$ were typically measured for penguins foraging in polar and subtropical frontal zones respectively. One of our male specimens showed higher $\delta^{13} \mathrm{C}$ values (on average $16.5 \%$ ), suggesting a feeding ground north of the Polar Front, in sub-Antarctic waters. Our study thus demonstrates the importance of intra-tooth analysis to describe individual foraging histories and how these translate at the population level. It is nonetheless necessary to expand our sampling, particularly for female specimens, to accurately describe the foraging strategy at the full SES population level. Interestingly, SES tooth synthesis starts during foetal life (McCann 1993), initial $\delta^{15} \mathrm{~N}$ and $\delta^{13} \mathrm{C}$ values being, in all likelihood, characteristics of the dentine synthesised during the last months of foetal growth. Prior to the establishment of the neonatal line, $\delta^{13} \mathrm{C}$ values of an individual SES are therefore likely to reflect the foraging strategy of the mother during her pregnancy. Initial $\delta^{13} \mathrm{C}$ values of male and female teeth ranged from -17 to $-21 \%$, suggesting that adult females forage in sub-Antarctic and Antarctic waters, a result consistent with those obtained on adult female blood samples (Bailleul et al. 2010). In the future, we should be able to investigate whether an individual is likely to forage as an adult in the same habitat as its mother.

Assuming that the carbon enrichment factor between diet and total dentine organic matter is similar to the estimated enrichment of 4 to $5 \%$ between diet and tooth collagen (Koch 2007; 5\%o for Mirounga angustirostris in Clementz et al. 2007), the potential $\delta^{13} \mathrm{C}$ diet of SES should vary from -25.3 to $-20.5 \%$. Isotopic data from SES and their potential prey items, taken from stomach content and fatty acids data, suggest that cephalopods are not the staple food of female elephant seals. Myctophids may be the dominant fish prey of SES (Cherel et al. 2008, Daneri \& Carlini 2002, Field et al. 2007b; David et al. 1999). The mean myctophid fish $\delta^{13} \mathrm{C}(-21 \%)$ reported in Cherel et al. (2008) varied within this range (Fig. 6). Moreover the mean $\delta^{15} \mathrm{~N}$ of the myctophid fish of $10 \%$ (Cherel et al. 2008) is also in the range of the expected diet values under an isotopic nitrogen enrichment of 3.4\% (DeNiro \& Epstein 1981).

One of our most interesting findings was the intraindividual variability in male dentine $\delta^{13} \mathrm{C}$ values,

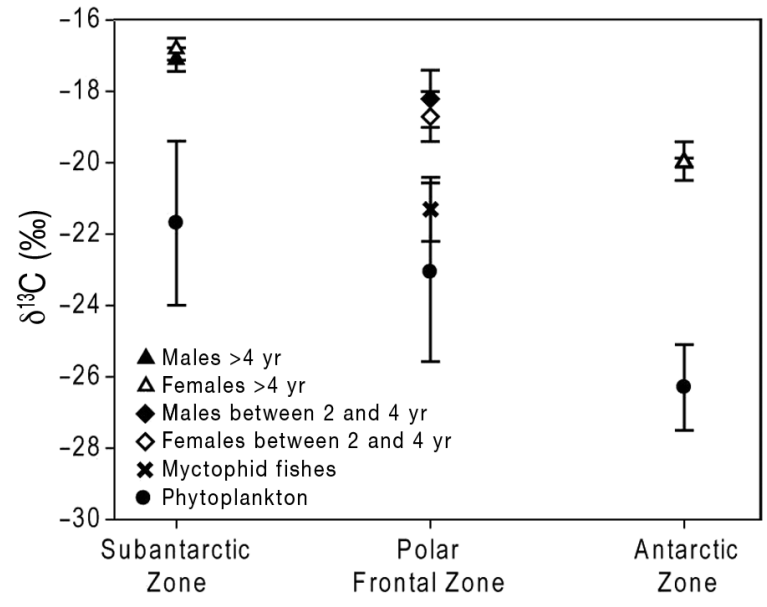

Fig. 6. Mirounga leonina. Carbon isotopic values in teeth by age category from this study, with literature values from myctophid fishes (Cherel et al. 2008, 2010) and from phytoplankton (Rau et al. 1992, François et al. 1993, Bentaleb \& Fontugne 1996, Bentaleb et al. 1998) from Kerguelen waters in relation to Southern Indian Ocean zones

with larger variations over the 2 to 4 yr age-class as compared to individuals older than 4 yr. Individual females were also found to exhibit a large variability within the 2 to 4 yr age-class. This result suggests that young juveniles, whether males or females, forage over a large range of habitats between the Polar Frontal Zone and Antarctic waters $\left(\delta^{13} \mathrm{C}\right.$ from -20.3 to $-16.5 \%$ ). This high intra-individual $\delta^{13} \mathrm{C}$ variability suggests that, during this period, SES are foraging over a broad range of habitat, possibly exploring their environment, looking for the best foraging zone. The low values and stability of $\delta^{15} \mathrm{~N}$ over this period suggests that all juvenile SES in our study fed at about the same low trophic level, whatever their foraging zone. As they age, males appear to become resident to their foraging habitat year after year, as indicated by the lower intra-individual variability in $\delta^{13} \mathrm{C}$ observed after 4 yr. From a consecutive tracking study, Bradshaw et al. (2004) showed that adult females return to the same foraging zone in consecutive foraging trips, and hypothesized that this longterm fidelity may confer ecological benefits over an individual's lifetime, even when energy gain is not consistently high in all years. The selective advantage of developing fidelity to a foraging zone early in life may result from the higher probability of obtaining appropriate food stores for maintenance and reproduction, after learning successful foraging routes as juveniles (McConnell et al. 2002). However, this long-term foraging fidelity of adults might limit the individual's ability to change foraging habitats in scenarios of global changes. This finding has strong 
implications for survival of this species. Our results suggest that such adjustment is more likely to occur via the juvenile component of the SES population.

\section{CONCLUSIONS}

The study of growth layers of marine SES teeth has demonstrated that dentine preserves a high-resolution chronological isotopic record of the individuals' physiological history and foraging strategy. This isotopic approach provides evidence of ontogenetic spatial and trophic changes in SES foraging. Female and male SES share approximately the same foraging area, between the Polar Frontal Zone and Antarctic waters, during their first $4 \mathrm{yr}$. In our study, after $4 \mathrm{yr}$, male and some female SES became resident to a well defined foraging zone, either in Antarctic waters or in the Polar Frontal Zone and sub-Antarctic waters. While females feed at the same trophic level until $4 \mathrm{yr}$ of age according to our longitudinal data, and all their life as suggested by Bailleul et al. (2010) using crosssectional blood isotopic data, males increase their trophic level after $4 \mathrm{yr}$, probably consuming larger prey as they grow. Nonetheless, blood isotopic samples need to be corroborated by intra-tooth analysis on older females in order to ascertain that the trophic levels of females remain stable with age. These results confirm that, as they grow, SES travel farther away and spend more time in southerly regions (Field et al. 2005). In a way, adult males adapt their foraging strategy by consuming larger prey to meet their higher energetic requirements. Their foraging strategy differs from the female strategy only by the size of prey, not by foraging area.

Acknowledgements. This project was conducted as part of the Investigation of the vulnerability of the Productivity of the Southern Ocean Subsystems to climate change: the southern elephant seal Assessment from mid to high Latitudes (ANRVMC IPSOS-SEAL). We are thankful to the Agence Nationale pour la Recherche and the Total Fondation for their financial support. This study is part of a national research program, supported by the Institut Polaire Français Paul Émile Victor (Program no. 109, contact H. Weimerskirch). We are thankful to $\mathrm{M}$. Authier and 2 anonymous reviewers for their comments on an earlier version of this paper. We are very grateful to all who participated in the fieldwork, including collection of the elephant seal teeth. Publication ISE-M no. ISEM 2011-079.

\section{LITERATURE CITED}

Ambrose SH (1990) Preparation and characterization of bone and tooth collagen for isotopic analysis. J Archaeol Sci 17:431-451
Andersson M (1994) Sexual selection. Princeton University Press, Princeton, NJ

Authier M, Delord K, Guinet C (2011) Population trends of female elephant seals breeding on the Courbet Peninsula, îles Kerguelen. Polar Biol 34:319-328

Bailleul F, Charrassin JB, Ezraty R, Girard-Ardhuin F, McMahon CR, Field IC, Guinet C (2007) Southern elephant seals from Kerguelen Islands confronted by Antarctic sea ice: changes in movements and in diving behaviour. Deep-Sea Res II 54:343-355

Bailleul F, Authier M, Ducatez S, Roquet F, Charrassin JB, Cherel Y, Guinet C (2010) Looking at the unseen: combining animal bio-logging and stable isotopes to reveal a shift in the ecological niche of a deep diving predator. Ecography 33:709-710

Balasse M, Bocherens H, Mariotti A, Ambrose SH (2001) Detection of dietary changes by intra-tooth carbon and nitrogen isotopic analysis: an experimental study of dentine collagen of cattle (Bos taurus). J Archaeol Sci 28: 235-245

Bentaleb I, Fontugne M (1996) Anthropogenic $\mathrm{CO}_{2}$ invasion of the surface ocean: its influence on the organic carbon isotope composition of phytoplankton. Cr Acad Sci II A 322:743-748

Bentaleb I, Fontugne M, Descolas-Gros C, Girardin C and others (1998) Carbon isotopic fractionation by plankton in the Southern Indian Ocean: Relationship between $\delta^{13} \mathrm{C}$ of particulate organic carbon and dissolved carbon dioxide. J Mar Syst 17:39-58

Biuw M, Boehme L, Guinet C, Hindell MA and others (2007) Variations in behavior and condition of a Southern Ocean top predator in relation to in situ oceanographic conditions. Proc Natl Acad Sci USA 104:13705-13710

Bolnick DI, Svanbäck R, Fordyce JA, Yang LH, Davis JM, Hulsey CD, Forister ML (2003) The ecology of individuals: incidence and implications of individual specialization. Am Nat 161:1-28

Boyd IL, Arnbom TA, Fedak MA (1994) Biomass and energy consumption of the South Georgia stock of southern elephant seals. In: LeBoeuf BJ, Laws RM (eds) Elephant seals: population ecology, behavior and physiology. University of California Press, Los Angeles, CA, p 98-120

> Bradshaw CJA, Hindell MA, Sumner MD, Michael KJ (2004) Loyalty pays: potential life history consequences of fidelity to marine foraging regions by southern elephant seals. Anim Behav 68:1349-1360

Carrick R, Ingham SE (1962) Studies on the southern elephant seal, Mirounga leonina (L.) II. Canine tooth structure in relation to function and age determination. Wildl Res 7:102-118

- Cherel Y, Hobson KA (2007) Geographical variation in carbon stable isotope signatures of marine predators: a tool to investigate their foraging areas in the Southern Ocean. Mar Ecol Prog Ser 329:281-287

> Cherel Y, Hobson KA, Guinet C, Vanpe C (2007) Stable isotopes document seasonal changes in trophic niches and winter foraging individual specialization in diving predators from the Southern Ocean. J Anim Ecol 76:826-836

Cherel Y, Ducatez S, Fontaine C, Richard P, Guinet C (2008) Stable isotopes reveal the trophic position and mesopelagic fish diet of female southern elephant seals breeding on the Kerguelen Islands. Mar Ecol Prog Ser 370: 239-247

Cherel Y, Fontaine C, Richard P, Labat JP (2010) Isotopic niches and trophic levels of myctophid fishes and their 
predators in the Southern Ocean. Limnol Oceanogr 55: 324-334

> Clementz M, Koch P, Beck C (2007) Diet induced differences in carbon isotope fractionation between sirenians and terrestrial ungulates. Mar Biol 151:1773-1784

Daneri G, Carlini A (2002) Fish prey of southern elephant seals, Mirounga leonina, at King George Island. Polar Biol 25:739-743

David JB, Ian LB, Geoff CC, Patrick JB (1999) Fatty acid signature analysis from the milk of Antarctic fur seals and Southern elephant seals from South Georgia: implications for diet determination. Mar Ecol Prog Ser 187:251-263

DeNiro MJ, Epstein S (1978) Carbon isotopic evidence for different feeding patterns in two hyrax species occupying the same habitat. Science 201:906-908

DeNiro MJ, Epstein S (1981) Influence of diet on the distribution of nitrogen isotopes in animals. Geochim Cosmochim Acta 45:341-351

DeNiro MJ (1985) Postmortem preservation and alteration of in vivo bone collagen isotope ratios in relation to palaeodietary reconstruction. Nature 317:806-809

Dettman DL, Lohmann KC (1995) Microsampling carbonates for stable isotope and minor element analysis: physical separation of samples on a 20 micrometer scale. J Sediment Petrol 65:566-569

> Ducatez S, Dalloyau S, Richard P, Guinet C, Cherel Y (2008) Stable isotopes document winter trophic ecology and maternal investment of adult female southern elephant seals (Mirounga leonina) breeding at the Kerguelen Islands. Mar Biol 155:413-420

Field IC, Bradshaw CJA, Burton HR, Sumner MD, Hindell MA (2005) Resource partitioning through oceanic segregation of foraging juvenile southern elephant seals (Mirounga leonina). Oecologia 142:127-135

Field IC, Bradshaw CJA, Burton HR, Hindell MA (2007a) Differential resource allocation strategies in juvenile elephant seals in the highly seasonal Southern Ocean. Mar Ecol Prog Ser 331:281-290

Field IC, Bradshaw CJA, van den Hoff J, Burton HR, Hindell MA (2007b) Age-related shifts in the diet composition of southern elephant seals expand overall foraging niche. Mar Biol 150:1441-1452

François R, Altabet MA, Goericke R, McCorkle DC, Brunet C, Poisson A (1993) Changes in the $\delta^{13} \mathrm{C}$ of surface water particulate organic matter across the subtropical convergence in the SW Indian Ocean. Global Biogeochem Cycles 7:627-644

Goericke R, Fry B (1994) Variations of marine plankton $\delta^{13} \mathrm{C}$ with latitude, temperature, and dissolved $\mathrm{CO}_{2}$ in the world ocean. Global Biogeochem Cycles 8:85-90

$>$ Guinet C (1991) Growth from birth to weaning in the southern elephant seal (Mirounga leonina). J Mammal 72: $617-620$

Guinet C, Jouventin P, Weimerskirch H (1992) Population changes, movements of southern elephant seals on Crozet and Kerguelen Archipelagos in the last decades. Polar Biol 12:349-356

> Hanson NN, Wurster CM, Bird MI, Reid K, Boyd IL (2009) Intrinsic and extrinsic forcing in life histories: patterns of growth and stable isotopes in male Antarctic fur seal teeth. Mar Ecol Prog Ser 388:263-272

Hindell MA, Slip D, Burton HR (1991) The diving behavior of adult male and female southern elephant seals, Mirounga leonina (Pinnipedia, Phocidae). Aust J Zool 39: 595-619
Hobson KA (1999) Tracing origins and migration of wildlife using stable isotopes: a review. Oecologia 120:314-326

Hobson KA, Sease JL (1998) Stable isotope analyses of tooth annuli reveal temporal dietary records: an example using Steller sea lions. Mar Mamm Sci 14:116-129

Hobson KA, Piatt JF, Pitocchelli J (1994) Using stable isotopes to determine seabird trophic relationships. J Anim Ecol 63:786-798

Jenkins SG, Partridge ST, Stephenson TR, Farley SD, Robbins CT (2001) Nitrogen and carbon isotope fractionation between mothers, neonates, and nursing offspring. Oecologia 129:336-341

Kelly JF (2000) Stable isotopes of carbon and nitrogen in the study of avian and mammalian trophic ecology. Can J Zool 78:1-27

Koch PL (2007) Isotopic study of the biology of modern and fossil vertebates. In: Michener R, Lajtha K (eds) Stable isotopes in ecology and environmental science, 2nd edn. Blackwell Publishing, Boston, MA p 99-154

$>$ Laws RM (1952) A new method of age determination for mammals. Nature 169:972-973

Laws RM (1953) The elephant seal (Mirounga leonina Linn.). II. General, social and reproductive behavior. Falkland Islands Dependencies Survey scientific reports 13:1-88

Ling JK, Bryden MM (1992) Mirounga leonina. Mamm Species 391:1-8

McCann TS (1985) Size, status and demography of southern elephant seals (Mirounga leonina) populations. In: Ling JK, Bryden MM (eds) Studies of sea mammals in south latitudes. South Australian Museum, Adelaide, Australia, p 1-17

McCann TS (1993) Age determination. In: Laws RM (ed) Antarctic seals: research, methods and techniques. Press Syndicate of the University of Cambridge, UK p 199-226

McConnell B, Fedak M, Burton HR, Engelhard GH, Reijnders PJH (2002) Movements and foraging areas of naïve, recently weaned southern elephant seal pups. J Anim Ecol 71:65-78

McCutchan JH, Lewis WM, Kendall C, McGrath CC (2003) Variation in trophic shift for stable isotope ratios of carbon, nitrogen, and sulfur. Oikos 102:378-390

> McLaren IA (1993) Growth in pinnipeds. Biol Rev Camb Philos Soc 68:1-79

McMahon CR, Burton HR, Bester MN (2000) Weaning mass and the future survival of juvenile southern elephant seals, Mirounga leonina, at Macquarie Island. Antarct Sci 12:149-153

> McMahon CR, Bester MN, Burton HR, Hindell MA, Bradshaw CJA (2005) Population status, trends and a reexamination of the hypotheses explaining the recent declines of the Southern elephant seal Mirounga leonina. Mammal Rev 35:82-100

Michener RH, Schell DM (1994) Stable isotope ratios as tracers in marine aquatic food webs. In: Lajtha K, Michener $\mathrm{RH}$ (eds) Stable isotopes in ecology and environmental science. Blackwell Scientific, Oxford, UK, p 138-158

$>$ Newland C, Field IC, Nichols PD, Bradshaw CJA, Hindell MA (2009) Blubber fatty acid profiles indicate dietary resource partitioning between adult and juvenile southern elephant seals. Mar Ecol Prog Ser 384:303-312

> Newsome SD, Koch PL, Etnier MA, Aurioles-Gamboa D (2006) Using carbon and nitrogen isotope values to investigate maternal strategies in northeast pacific otariids. Mar Mamm Sci 22:556-572

Newsome SD, Martinez del Rio C, Bearhop S, Phillips DL 
(2007a) A niche for isotopic ecology. Front Ecol Environ 5:429-436

Newsome SD, Etnier MA, Kurle CM, Waldbauer JR, Chamberlain CP, Koch PL (2007b) Historic decline in primary productivity in western Gulf of Alaska and eastern Bering Sea: isotopic analysis of northern fur seal teeth. Mar Ecol Prog Ser 332:211-224

Newsome SD, Clementz MT, Koch PL (2010) Using stable isotope biogeochemistry to study marine mammal ecology. Mar Mamm Sci 26:509-572

Perrin WF, Myrick AC (1980) Age determination of toothed whales and sirenians. International Whaling Commission, Cambridge, UK

Pistorius PA, Bester MN, Kirkman SP, Taylor FE (2001) Temporal changes in fecundity and age at sexual maturity of southern elephant seals at Marion Island. Polar Biol 24: 343-348

Polis A (1984) Age structure component of niche width and intraspecific resource partitioning: Can age groups function as ecological species? Am Nat 123:541-564

Rau GH, Takahashi T, Marais DJD (1989) Latitudinal variations in plankton $\delta^{13} \mathrm{C}$ : implications for $\mathrm{CO}_{2}$ and productivity in past oceans. Nature 341:516-518

Rau GH, Takahashi T, Des Marais DJ, Repeta DJ, Martin JH

Editorial responsibility: Matthias Seaman, Oldendorf/Luhe, Germany
(1992) The relationship between $\delta^{13} \mathrm{C}$ of organic matter and $\left[\mathrm{CO}_{2}(\mathrm{aq})\right]$ in ocean surface water: data from a JGOFS site in the northeast Atlantic Ocean and a model. Geochim Cosmochim Acta 56:1413-1419

Schoener TW (1989) The ecological niche. In: Cherrett JM (ed) Ecological concepts. Blackwell Science, Oxford, UK, p 79-113

Schulting RJ, Blockley SM, Bocherens $H$, Drucker D, Richards M (2008) Stable carbon and nitrogen isotope analysis on human remains from the Early Mesolithic site of La Vergne (Charente-Maritime, France). J Archaeol Sci 35:763-772

- Trull TW, Armand L (2001) Insights into Southern Ocean carbon export from the $\delta^{13} \mathrm{C}$ of particles and dissolved inorganic carbon during the SOIREE iron release experiment. Deep-Sea Res II 48:2655-2680

> Weimerskirch H, Inchausti P, Guinet C, Barbraud C (2003) Trends in bird and seal populations as indicators of a system shift in the Southern Ocean. Antarct Sci 15:249-256

Wurster CM, Petterson WP, Cheatham MM (1999) Advances in micromilling techniques: a new apparatus for acquiring high-resolution oxygen and carbon stable isotope values and major/minor elemental ratios from accretionary carbonate. Comput Geosci 25:1159-1166

Submitted: November 5, 2010; Accepted: July 29, 2011 Proofs received from author(s): October 14, 2011 